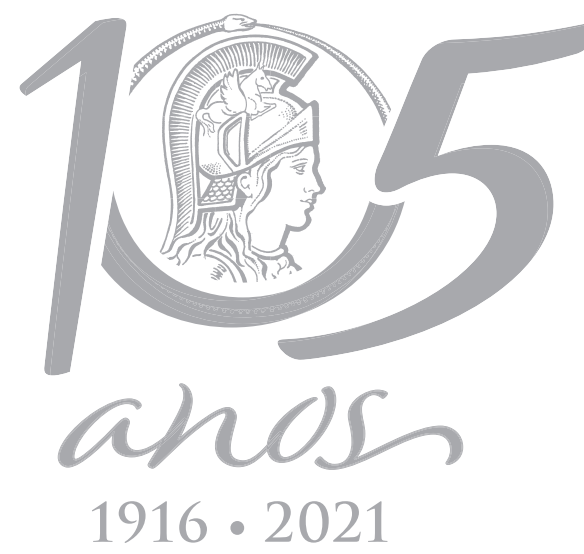

\title{
ECOSYSTEMS
}

\section{Effects of pyrimethanil fungicide on Chironomidae community structure}

\author{
JOSÉ LEONARDO DA SILVA MELLO, VANESSA COLOMBO, GUILHERME ROSSI \\ GORNI \& JULIANO J. CORBI
}

\begin{abstract}
The use of agrochemicals in agriculture may impact aquatic ecosystems, particularly influencing the stream insect communities. Among aquatic insects, the family Chironomidae is the most abundant and species-diverse insect group found in freshwater ecosystems. However, in the southern hemisphere, studies with Chironomidae are still sparse, compared to Europe and North America. The present study evaluates the responses of Chironomidae species (Insecta: Diptera) to pyrimethanil fungicide in a mesocosm experiment. Water contamination and chironomid community were monitored over 10 months. After five months of monitoring, the pyrimethanil fungicide was completely degraded and there was a statistically significant increase in the Margalef Richness and Shannon-Wiener Index $\left(\mathrm{H}^{\prime}\right)$ in the control units when compared with the contaminated mesocosms $(p=0.003)$. Our results point out that the utilization of agrochemicals can be a harmful factor influencing negatively the Chironomidae populations. This finding has key implications for insect conservation strategies and ecological management environments.
\end{abstract}

Key words: agrochemicals, aquatic insects, Chironomidae, agriculture, aquatic pollution.

\section{INTRODUCTION}

Agrochemicals pollution from farming exerts a toxic impact in the soil in the adjacent areas and on freshwater macroinvertebrates, frequently causing loss of sensitive insect orders such as Plecoptera(stoneflies), Ephemeroptera(mayflies) and Trichoptera (caddisflies) (Karouna-Renier \& Sparling 2001, Crisci-Bispo et al. 2007, Corbi et al. 2013). The occurrence of agrochemicals in aquatic systems continues to create major risks to non-target aquatic species (Liu et al. 2013, Shinn et al. 2015). Ecological disturbance caused by agrochemicals can potentially impact the microalgae community and therefore the system's primary productivity (Ferraz et al. 2004). Species richness is similarly influenced by these anthropogenic disturbances, which may lead to losses of taxa and cause spatial discontinuities in expected gradients (Bojsen \& Jacobsen 2003, Okano et al. 2017). Numerous freshwater biomonitoring plans use the macroinvertebrate community, particularly aquatic insects, as indicators of pollution, habitat modification, and water quality (Rosenberg 1992, Cranston 1995, Roque et al. 2000, Roy et al. 2003, Bonada et al. 2006, Carter et al. 2006, Hauer \& Resh 2006, Corbi \& Trivinho-Strixino 2008, 2017, Ferrington 2008, Corbi et al. 2011, Molozzi et al. 2012, Nicacio \& Juen 2015, Vanacker et al. 2018, Dodds \& Whiles 2020).

In most freshwater benthic communities, the Chironomidae is the most abundant and diverse insect group in freshwater systems (Rosenberg 1992, Cranston 1995, Roque et al. 2010, Corbi \& Trivinho-Strixino 2017). Chironomids are one of 
the most ubiquitous and species rich families of aquatic insects (Ferrington 2008, Merritt et al. 2008) and have received consideration by researchers worldwide due to their abilities as biological indicators of environmental conditions (Pinder 1986). A variety of chironomids have known tolerances to environmental gradients, which can be used to infer impacted ecosystems (Courtney \& Merritt 2008, Tang et al. 2009, Roque et al. 2010, Eggermont \& Heiri 2012, Corbi \& Trivinho-Strixino 2017, Corbi et al. 2019). The status of chironomid responses to fluctuations in the aquatic systems could permit their utilization to monitor streams, lakes and ponds (Rosenberg 1992). However, as pointed out by Nicacio \& Juen (2015), in the southern hemisphere, studies with Chironomidae are still sparse, compared to Europe and North America.

In recent years, the expansion of agricultural activities has resulted in increased use of pesticides and fertilizers (Corbi et al. 2006, 2018). Among these substances, pyrimethanil $\mathrm{N}$-(4,6-dimethylpyrimidin-2-il)-anilin fungicide is widely used in several types of agricultural crops around the world, as sugarcane and citrus (Verdisson et al. 2001, Anfossi et al. 2006, Seeland et al. 2013). The pyrimethanil (4,6-dimethyl-N-phenyl-2-pyrimidinamine) is one of the fungicides most widely used in monocultures and has been detected in aquatic ecosystems (Shinn et al. 2015, Araújo et al. 2015, Müller et al. 2019). According to EFSA (European Food Safety Authority 2006), pyrimethanil is a substance with minimal risk to human health, has poor water solubility and short degradation time, is not degraded by hydrolysis or photolysis in the aquatic environment. This fungicide can penetrate the plant cuticle where it is applied, acting to inhibit the secretion of fungal enzymes, which ultimately reduces dispersion of the fungus (EFSA 2006).
Among the recent studies and research relating to this agrochemical, Seeland et al. (2012), evaluated the effects of pyrimethanil in aquatic macroinvertebrates through ecotoxicological tests and showed that thermal and multigenerational effects should be considered when evaluating the ecotoxicity of pesticides and concluded that acute pyrimethanil -toxicity on Chironomus riparius increased with high temperature. Müller et al. (2012), evaluated the environmental risk of pyrimethanil in the context of climate changes, in the C. riparius, and they demonstrated that not only the impact of climate change, but also low concentrations of pesticides may pose a reasonable risk for aquatic insects in future. Shinn et al. (2015) studied the effects of pyrimethanil in the growth of algae Selenastrum capricornutum and showed that the presence of pyrimethanil in an aquatic system can cause immediate impact if it reaches concentrations close to $1.0 \mathrm{mg} \mathrm{L}^{-1}$ and Araújo et al. (2014), studied avoidance of fish (Danio rerio) in different concentrations of this fungicide. In this context, Araújo et al. (2015), also demonstrates that pyrimethanil is potentially toxic for many aquatic species, affecting survival, reproduction, feeding, growth, and that it can disturb the environmental quality; Baglieri et al. (2016) analyzed the possible use of Chlorella vulgaris and Scenedesmus quadricauda microalgae to degrade pyrimethanil fungicide in water; Colombo et al. (2017) concluded that the pyrimethanil fungicide applications, in agriculture cultivation, may lead to a decrease in Chironomus sancticaroli genetic diversity and Müller et al. (2019), studied the impact of pyrimethanil in the aquatic primary producers and shows that the growth of key structural macroalgae and macrophytes was affected by the fungicide. However, even with these studies, little is known about the relationship and influence of pyrimethanil fungicide in the 
structure and dynamics of the Chironomidae community.

The present study aimed to evaluate, through experimental field units, the effects of pyrimethanil fungicide on Chironomidae (Insecta: Diptera) community structure. The present study hypothesizes that the application of the fungicide pyrimethanil in agricultural areas, causes changes in the Chironomidae community structure of adjacent aquatic environment.

\section{MATERIALS AND METHODS}

\section{Mesocosms and water monitoring}

The present study was conducted at the Center for Water Resources and Applied Ecology (CRHEA), School of Engineering of São Carlos (EESC), University of São Paulo (USP), Brazil.

The mesocosm arrangement was composed of two treatments: non-contaminated controls and pyrimethanil treated tanks. Each mesocosm system consisted of $1500 \mathrm{~L}$ cylindrical tanks with 1.43/1.75 m (bottom/top) diameter and $0.83 \mathrm{~m}$ height, separated by 2 meters each one. All mesocosms had a layer of natural sediment and were filled with water pumped from the Lobo Reservoir (Itirapina, SP, Brazil) $22^{\circ} 10^{\prime} 0.5^{\prime \prime}(\mathrm{S})$ and $47^{\circ} 54^{\prime \prime} 10.51^{\prime \prime}$ (O) (Shinn et al. 2015). Throughout this same period (October 2012) the water source was known to be nontoxic to the fish Danio rerio and tadpoles of Leptodactylus latrans, Lithobates catesbeianus and Cladocera Ceriodaphnia silvestrii (Shinn et al. 2015). In order to avoid allochthonous material, the mesocosms were allocated 15 centimeters above the ground level. Water was removed from the Lobo Dam using a suction pump. To minimize the risk of overflows due to precipitation, holes were drilled at the edge of each mesocosm, in order to allow surplus water to escape. Subsequently, specimens of aquatic macrophytes rooted in the sediment at the same volume in each mesocosms.

The commercial formulation Mythos ${ }^{\circledR}$, which contains $300 \mathrm{~g} . \mathrm{L}^{-1}$ of pyrimethanil as active ingredient, was dissolved in distilled water and added to the treated mesocosms to a final nominal pyrimethanil concentration of $1 \mathrm{mg} \cdot \mathrm{L}^{-1}$, which corresponds to the chronic LOEC (lowest observed effect concentration) for Daphnia magna species reproduction (Seeland et al. 2012). The mesocosms were organized in two groups, each with three replicates. Units 1, 3 and 4 served as treatments and the second group served as controls (units 2, 5 and 6). The mesocosms contamination occurred in October $20^{\text {th }}, 2012$ (Figure 1). The use of the commercial formulation instead of pure active ingredient was preferred as we consider it the most environmentally relevant approach to be tested in outdoor mesocosm systems (Shinn et al. 2015).

Physical and chemical variables, such $\mathrm{pH}$, temperature, conductivity and dissolved oxygen, were measured with the aid of a multiparameter water quality probe (Horiba ${ }^{\circledR}$ U10). Water monitoring was performed monthly over the period between October 2012 and August 2013. Pyrimethanil concentrations were confirmed and determined by high-performance liquid chromatography - (HPLC) according to Müller et al. (2012). The analyses for pyrimethanil determination concentrations were carried out at the Chemistry Institute of the University of São Paulo (IQSC/USP).

\section{Chironomidae sampling}

Chironomidae fauna were collected monthly, with a core sampler, during October 2012 and August 2013. Following the sampling procedures, the material collected was stored in 70\% alcohol. Chironomidae were identified to morphospecies using appropriate keys (Trivinho-Strixino \& Strixino 1995, Trivinho-Strixino 2011). The 
individuals collected were quantified to determine the chironomids community structure present in each mesocosm. After characterizing the aquatic community, the Margalef richness and ShannonWiener diversity index $\left(H^{\prime}\right)$ were assessed.

\section{Statistical Analysis}

The Margalef Richness Index and ShannonWiener Diversity Index, which assessed differences between control and treatment mesocosms, were calculated using the PAST (Paleontological statistics) software, version 3.14 (Hammer et al. 2001). We also applied a t-tests $(\alpha=0.05)$, to analyze the significative differences in these indices between contaminated and control units. The comparison between the water variables was performed using t-tests ( $\alpha=$ 0.05), with the aid of software R Project, version 3.3.1. (R Core Team 2016).

\section{RESULTS}

\section{Water analyses and pyrimethanil concentration}

The analysis related to the water variables showed no statistically significant differences between controls and treatment mesocosms. At the beginning of the monitoring, the pyrimethanil concentrations found in the three treatment mesocosms showed similar values to $1.40(0.06) \mathrm{mg} \cdot \mathrm{L}^{-1}$. The complete degradation of pyrimethanil occurred in the fifth month of monitoring (Figure 1). The $\mathrm{p}$-values for $\mathrm{pH}$, temperature, dissolved oxygen and conductivity were all higher than 0.05 .

\section{Chironomidae community}

In total, 1263 individuals from two Chironomidae subfamilies were collected: Chironominae and Tanypodinae. Seven different genera from eight distinct species were identified. The individuals and their occurrence and distribution in the mesocosms are listed in Table I and Figure 2.

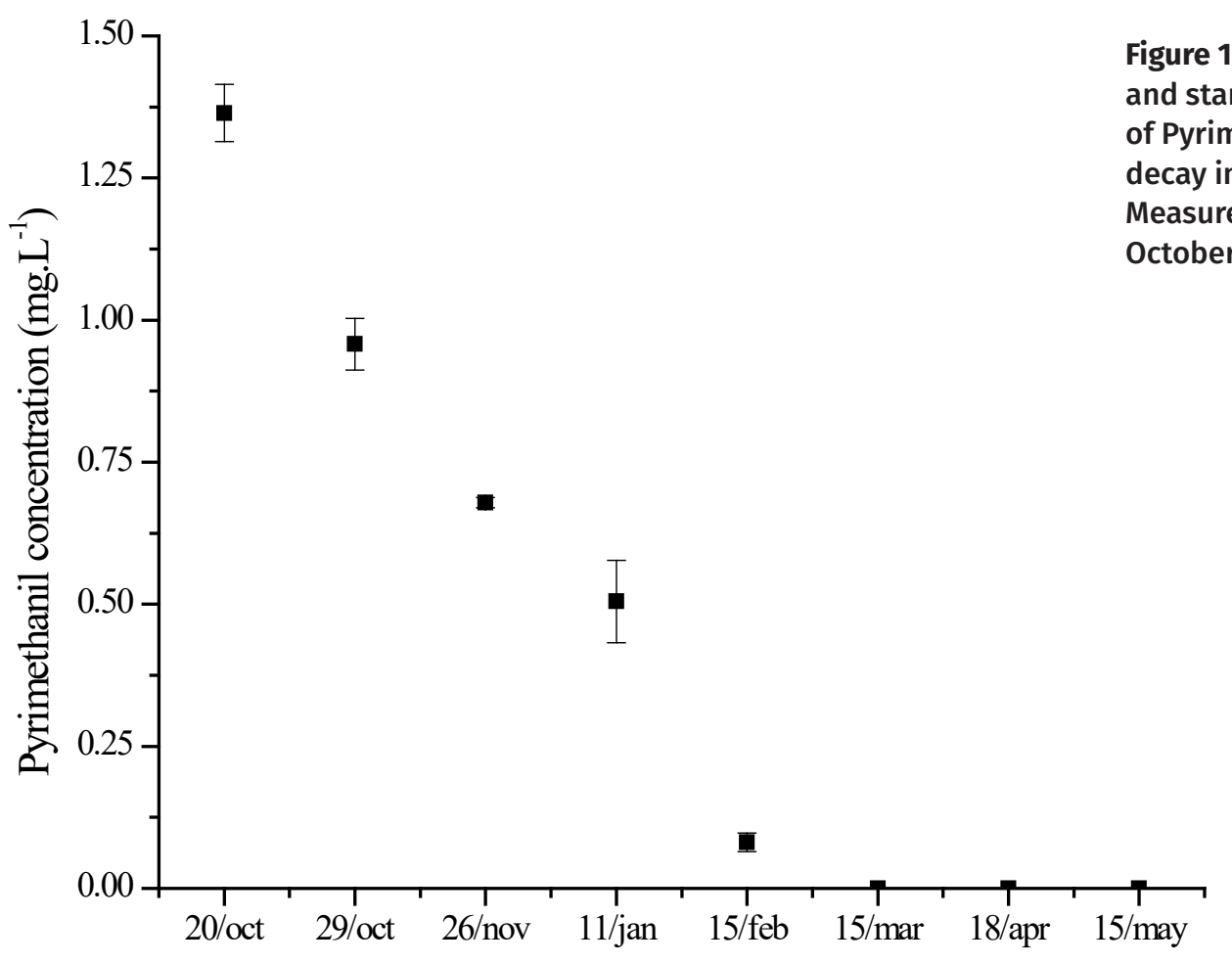




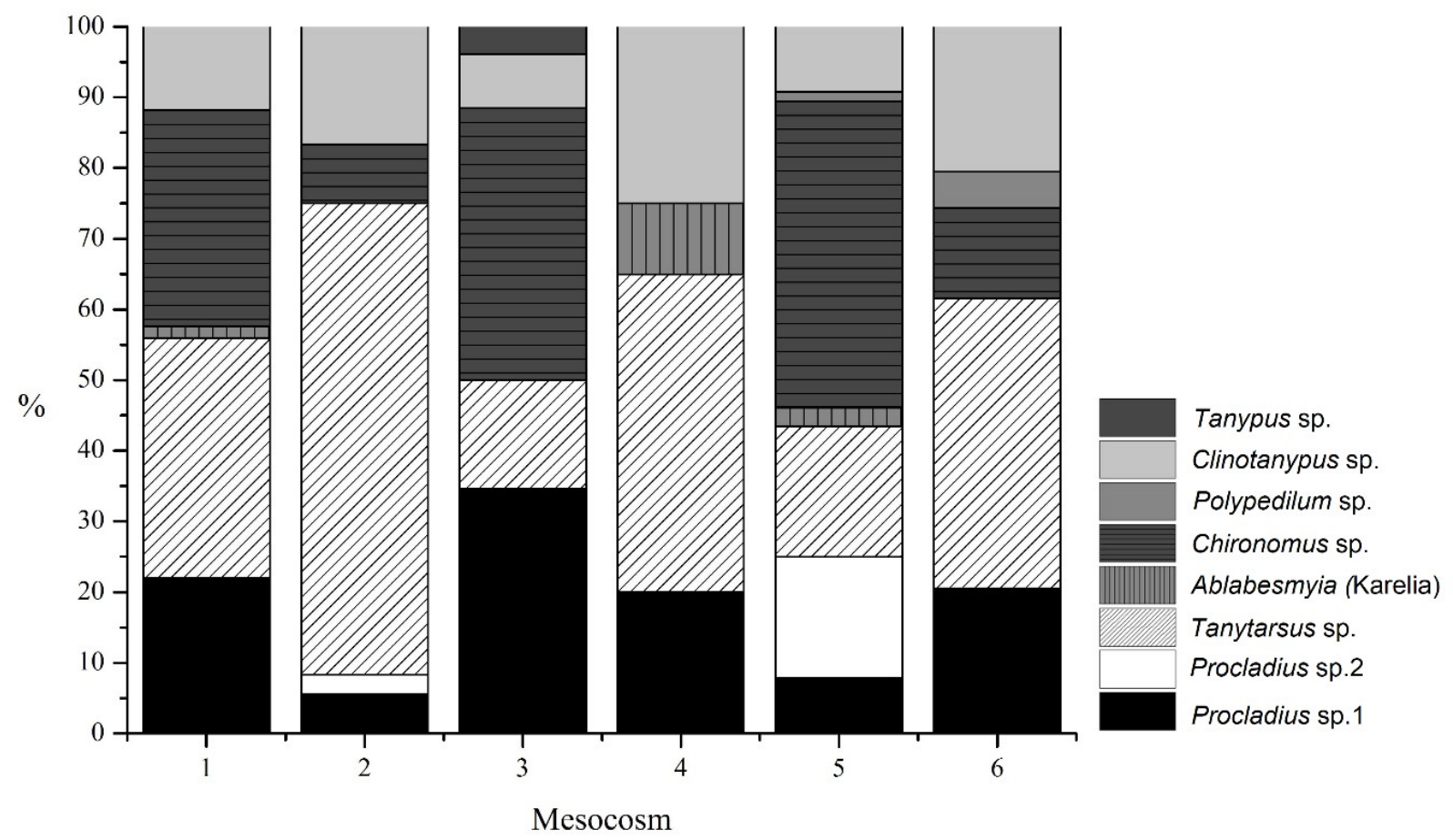

Figure 2. Chironomid species distribution (\%) in the six mesocosms. Mesocosms 1, 3 and 4, with Pyrimethanil fungicide and mesocosms 2, 5 and 6, without Pyrimethanil.

Table I. Chironomidae abundance in the treated and control mesocosms, during the experiments.

\begin{tabular}{|c|c|c|c|c|c|c|c|c|c|c|c|c|c|c|c|c|c|c|}
\hline \multirow{2}{*}{$\begin{array}{c}\text { Sample dates } \\
\text { Taxa/Mesocosms* }\end{array}$} & \multicolumn{2}{|c|}{ Oct./12 } & \multicolumn{2}{|c|}{ Nov./12 } & \multicolumn{2}{|c|}{ Jan./13 } & \multicolumn{2}{|c|}{ Feb./13 } & \multicolumn{2}{|c|}{ Mar./13 } & \multicolumn{2}{|c|}{ Apr./13 } & \multicolumn{2}{|c|}{ May/13 } & \multicolumn{2}{|c|}{ Jun./13 } & \multicolumn{2}{|c|}{ Jul./13 } \\
\hline & $\mathbf{T}$ & C & $\mathbf{T}$ & C & $\mathbf{T}$ & C & $\mathbf{T}$ & C & $\mathbf{T}$ & C & $\mathbf{T}$ & C & $\mathbf{T}$ & C & $\mathbf{T}$ & c & $\mathbf{T}$ & C \\
\hline Procladius sp. 1 & 4 & 1 & 3 & 2 & U & U & 0 & 4 & $J$ & & 2 & 1 & 2 & 1 & 5 & 0 & 0 & 3 \\
\hline Procladius sp. 2 & 0 & 2 & 0 & 0 & 0 & 1 & 0 & 1 & 0 & 0 & 0 & 4 & 0 & 4 & 0 & 2 & 0 & 1 \\
\hline Tanytarsus sp. & 7 & 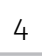 & 0 & 2 & 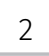 & 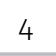 & & 9 & & & 12 & 16 & 0 & 16 & 1 & 4 & 1 & 3 \\
\hline $\begin{array}{c}\text { Ablabesmyia } \\
\text { (Karelia) }\end{array}$ & 0 & 0 & 0 & 0 & 1 & 0 & 0 & 0 & 0 & 0 & 0 & 0 & 0 & 0 & 1 & 0 & 0 & 1 \\
\hline Chironomus sp. & 0 & 2 & 0 & 1 & 0 & 0 & 2 & 18 & 7 & 13 & 0 & 3 & 1 & 3 & 5 & 0 & 2 & 2 \\
\hline Polypedilum sp. & 0 & 0 & 0 & 1 & 0 & 0 & 0 & 0 & 0 & 0 & 0 & 1 & 0 & 1 & 0 & 0 & 0 & 0 \\
\hline Clinotanypus sp. & 0 & 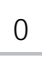 & 0 & 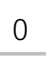 & 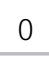 & 0 & 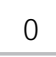 & r. & 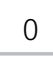 & . & 1 & 3 & 1 & 3 & 6 & 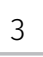 & 1 & 2 \\
\hline Tanypus sp. & 0 & 0 & 0 & 0 & 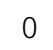 & 0 & 1 & 0 & 0 & 0 & 0 & 0 & 0 & 0 & 0 & 0 & 0 & 0 \\
\hline
\end{tabular}

Margalef richness and Shannon-Wiener diversity $\left(H^{\prime}\right)$ in the treatment mesocosms were low at the beginning of the experiment when compared with the values of control mesocosms. After the complete pyrimethanil degradation, the metrics of treatment mesocosms began to increase with values like those obtained in the control's units. The Margalef richness and Shannon-Wiener diversity $\left(H^{\prime}\right)$ values in mesocosms are presented in Figure 3 and Figure 4 , respectively. 


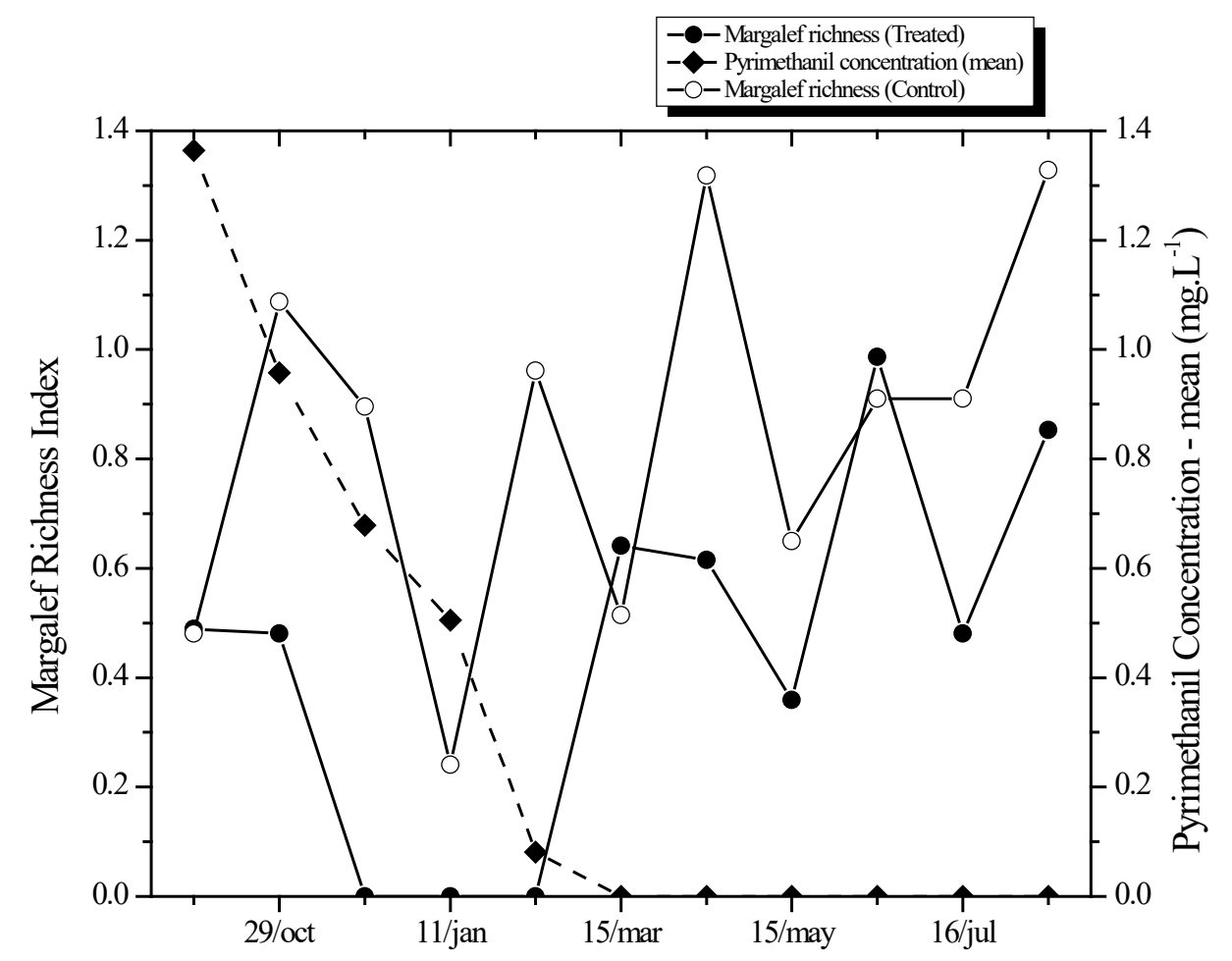

Figure 3. Margalef Richness index mean values in mesocosms and Pyrimethanil concentration mean. Measures obtained from October 2012 to July 2013.
The t-test, applied to diversity and species richness indexes between the treatment and control mesocosms, showed significant differences ( $p=0.003)$ among the units.

\section{DISCUSSION}

The present study hypothesizes that the application of the fungicide pyrimethanil in agricultural areas, causes changes in the Chironomidae community of adjacent aquatic environments. The understanding of anthropogenic stressors effect, such as pyrimethanil fungicide, in the Chironomidae organism's distribution and abundance is fundamental to the evaluation of impacts on aquatic environments (Carter et al. 2006), especially in streams adjacent to agricultural crops. Other studies also pointed to the loss of Chironomidae diversity and richness species in areas with agriculture impacts in Neotropical streams (Corbi \& Trivinho-Strixino 2006, Kleine et al. 2011, Corbi et al. 2018).

The low species richness observed in the six mesocosms and great homogeneity can be explained in several ways. According to Bojsen \& Jacobsen (2003), water bodies located in open areas without riparian vegetation, have characteristics favoring the increase of periphyton biomass, due to the high incidence of light and the absence of organic matter, providing the presence of scrapers groups. Despite the low Chironomidae richness observed in the six mesocosms, the units without contamination presented higher richness. Caquet et al. (2000) showed in their experiments with mesocosms simulating lentic environments, that the spontaneous colonization of insects can require several months to occur. On the other hand, in the following months of pyrimethanil degradation, there was continuous recovery of the Chironomidae community. 


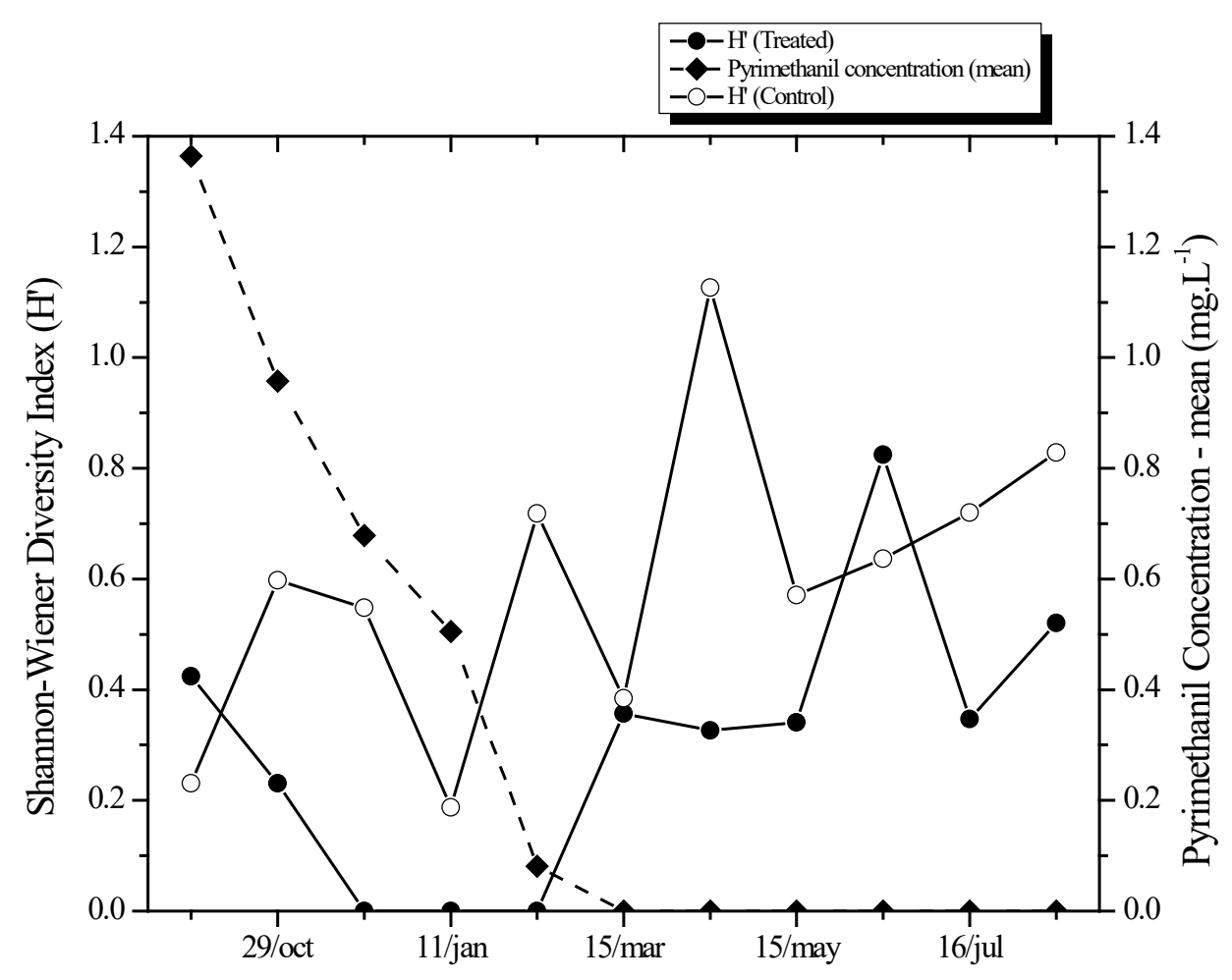

Figure 4. ShannonWiener diversity index mean values in mesocosms and Pyrimethanil concentration mean. Measures obtained from October 2012 to July 2013.
The environmental monitoring conducted in the six mesocosms, linked to methodologies and approaches of ecotoxicology, can provide insights into the mechanisms that act on the Chironomidae community dynamics and structure, especially when evaluating the effects of a harmful substance on groups of great environment importance (Ferrington 2008). This study showed a decrease in the chironomid community in experiments contaminated with pyrimethanil fungicide. The loss of Chironomidae diversity in aquatic environments can result in loss of different functions in these environments, such as the reduction fish species and nutrient cycling in this environment as suggested by several researchers (Cranston 1995, Trivinho-Strixino \& Strixino 1995, Roque et al. 2000, Ferrington 2008). A study conducted by Colombo et al. (2017), showed that pyrimethanil fungicide can reduce the genetic diversity of Chironomus sancticaroli species (Diptera: Chironomidae) exposed to different pyrimethanil concentrations. In this study, the authors concluded that the pyrimethanil applications in agriculture cultivation, may lead to a decrease in aquatic biota genetic diversity. This condition may begin the disappearance of species in the long term-exposure, common situations in Brazilian agriculture and would have significant consequences for conservation plans and ecological managing.

The high temperature observed in the tropical regions can also be determinant to the low Chironomidae diversity in the pyrimethanil contaminated sites. Similar observations were made by Seeland et al. (2012), who found that pyrimethanil -toxicity on Chironomus riparius increased with elevated temperature. Similarly, Seeland et al. (2013) also stated that the life-stage specific temperature-dependent ecotoxicity of pyrimethanil demonstrate the complexity of pesticide-temperature interactions, especially considering global climate change predictions. 
This research demonstrates the negative effects of pyrimethanil fungicide, which may contaminate streams adjacent to agricultural areas, via runoff process. In Brazil, it's also knows that the application of agrotoxics, as Pyrimethanil, together with the problem of the devastation of riparian vegetation, has led to different impacts on the water resources of the neighboring areas. The present study contributes to the evaluation of dynamics of the Chironomidae community structure in relation to contamination by Pyrimethanil, extensively used in the agriculture fields around the world. Our results point out that the utilization of agrochemicals can be a harmful factor influencing the Chironomidae populations. This finding has important implications for insect's conservation strategies and ecological management environments.

\section{Acknowledgments}

We would like to thank the Coordenação de Aperfeiçoamento de Pessoal de Nivel Superior (CAPES) for granting the scholarship. We thank professor Evaldo L. G. Espindola for the partnership and suggestions. We also thank Fundação de Amparo à Pesquisa do Estado de São Paulo (FAPESP) for the financial support, process number 2013/24268-2.

\section{REFERENCES}

ANFOSSI L, SALES P \& VANNI A. 2006. Degradation of anilinopyrimidine fungicides photoinduced by iron (III)polycarboxylate complexes. Pest Manag Sci 62: 872-879.

ARAÚJO CV, SHINN C, MENDES LB, DELELLO-SCHNEIDER D, SANCHEZ AL \& ESPÍNDOLA EL. 2014. Avoidance response of Danio rerio to a fungicide in a linear contamination gradient. Sci Total Environ 484: 36-42.

ARAÚJO CV, SHINN C, MÜLLER R, MOREIRA-SANTOS M, ESPÍNDOLA EL \& RIBEIRO R. 2015. The ecotoxicity of pyrimethanil for aquatic biota in. Toxicity and Hazard of Agrochemicals, p. 127.

BAGLIERI A, SIDELLA S, BARONE V, FRAGALÀ F, SILKINA A, NĖGRE M \& GENNARI M. 2016. Cultivating Chlorella vulgaris and Scenedesmus quadricauda microalgae to degrade inorganic compounds and pesticides in water. Environ Sci Pollut Res 23: 18165-18174.

BOJSEN BH \& JACOBSEN D. 2003. Effects of deforestation on macroinvertebrate diversity and assemblage structure in Ecuadorian Amazon streams. Arch Für Hydrobiol 158: 317-342.

BONADA N, PRAT N, RESH VH \& STATZNER B. 2006. Developments in aquatic insect biomonitoring: $A$ comparative analysis of recent approaches. Annu Rev Entomol 51: 495-523.

CAQUET T, LAGADIC L \& SHEFFIELD SR 2000. Mesocosms in Ecotoxicology: Outdoor Aquatic Systems. Rev Environ Contam Toxicol 165: 1-38.

CARTER JL, RESH VH, HANNAFORD MJ, \& MYERS MJ. 2006. Macroinvertebrates as Biotic Indicators of Environmental Quality. In: Hauer FR \& Lamberti GA (Eds), Methods in stream ecology, San Diego: Academic Press, USA, p. 805-831.

COLOMBO V, GORNI GR, FALCOSKI TO, COSTA PI \& CORBI JJ. 2017. Genetic diversity loss in Chironomus sancticaroli (Diptera: Chironomidae) exposed to Pyrimethanil fungicide: an analysis using RAPD technique. Water Air Soil Pollut 228: 228-339.

CORBI JJ \& TRIVINHO-STRIXINO S. 2002. Spatial and bathymetric distribution of the microbenthic fauna of the Ribeirão das Anhumas reservoir (Américo Brasiliense, SP, Brazil). Acta Limnol Bras 14: 35-42.

CORBI JJ, TRIVINHO-STRIXINO S, DOS SANTOS A \& DEL GRANDE M. 2006. Diagnóstico ambiental de metais e organoclorados em córregos adjacentes a áreas de cultivo de cana-deaçúcar (Estado de São Paulo, Brasil). Quim Nova 29: 61-65.

CORBI JJ \& TRIVINHO-STRIXINO S. 2008. Relationship between Sugar Cane Cultivation and Stream Macroinvertebrate Communities. Braz Arch Biol Technol 51: 769-779.

CORBI JJ, FROEHLICH CG, TRIVINHO-STRIXINO S \& SANTOS A. 2011. Evaluating the use of predatory insects as bioindicators of metals contamination due to sugarcane cultivation in neotropical streams. Environ Monit Assess 177: 545-554.

CORBI JJ, KLEINE P \& TRIVINHO-STRIXINO S. 2013. Are aquatic insect species sensitive to banana plant cultivation? Ecol Ind 25: 156-161.

CORBI JJ \& TRIVINHO-STRIXINO S. 2017. Chironomid species are sensitive to sugarcane cultivation. Hydrobiologia 785: 91-99.

CORBI JJ, GEROMEL-COSTA CGA, COLOMBO V, GORNI GR \& RIOS L. 2018. Environmental diagnosis of metals in streams 
near sugarcane cultivation areas: current and historical analysis in the central region of the State of São Paulo. An Acad Bras Cienc 90: 2711-2719.

COURTNEY GW \& MERRITT RW. 2008. Larvae of aquatic Diptera. An Introduction to the Aquatic Insects of North America. In: Merritt RW, Cummins KW \& Berg MB (Eds), Iowa: Kendall Hunt Publishing Company, USA, p. 687-722.

CRANSTON PJ. 1995. Chironomids: From Genes to Ecosystems. CSIRO. Canberra, Australia.

CRISCI-BISPO VL, BISPO PC \& FROEHLICH CG. 2007. Ephemeroptera, Plecoptera and Trichoptera assemblages in litter in a mountain stream of the Atlantic rainforest from Southeast Brazil. Rev Bras Zool 24: 545-551.

DODDS WK \& WHILES MR. 2020. Freshwater ecology: Concepts and enviromental applications of limnology. third edition, Academic Press.

EGGERMONT H \& HEIRI O. 2012. The chironomidtemperature relationship: expression in nature and palaeoenvironmental implications. Biol Rev 87: 430-456.

EFSA - EUROPEAN FOOD SAFETY AUTHORITY. 2006. Conclusion regarding the peer review of the pesticide risk assessment of the active substance Pyrimethanil. Sci Rep 61: 1-70.

FERRAZ DGB, SABATER C \& CARRASCO JM. 2004. Effects of propanil, tebufenozide and mefenacet on growth of four freshwater species of phytoplankton: a microplate bioassay. Chemosphere 56: 315-320.

FERRINGTON LC. 2008. Global diversity of non-biting midges (Chironomidae; Insecta-Diptera) in freshwater. Hydrobiologia 595: 447-455.

HAMMER Ф, HARPER DAT \& RYAN PD. 2001. PAST: Paleontological Statistics Software Package for Education and Data Analysis. Palaeontol Electron 4: 9.

HAUER FR \& RESH VH. 2006. Macroinvertebrates. In: Hauer FH \& Lamberti GA (Eds), Methods in stream ecology, San Diego: Academic Press, USA p. 435-454.

KAROUNA-RENIER NK \& SPARLING DW. 2001. Relationships between ambient geochemistry, watershed land-use and trace metal concentrations in aquatic invertebrates living in storm water treatment ponds. Environ Pollut 112: 183-192.

KLEINE P, TRIVINHO-STRIXINO S \& CORBI JJ. 2011. Relationship between banana plant cultivation and stream macroinvertebrate communities. Acta Limnol Bras. 23: 344-352.
LIU SS, WANG CL, ZHANG J, ZHU XW \& LI WY. 2013. Combined toxicity of pesticide mixtures on green algae and photobacteria. Ecotoxicol Environ Safe 95: 98-103.

MERRITT RW, CUMMINS KW \& BERG MB. 2008. An introduction to the aquatic insects of North America. $4^{\text {th }}$ edition. Kendall/Hunt Publishers, Dubuque, Iowa.

MOLOZZI J, FEIO MJ, SALAS F, MARQUES JC \& CALLISTO M. 2012. Development and test of a statistical model for the ecological assessment of tropical reservoirs based on benthic macroinvertebrates. Ecol Ind 23: 155-165.

MÜLLER R, SEELAND A, JAGODZINSKI LS, DIOGO JB, NOWAK C \& OEHLMANN J. 2012. Simulated climate change conditions unveil the toxic potential of the fungicide Pyrimethanil on the midge Chironomus riparius: a multigeneration experiment. Ecol Evolution 2: 196-210.

MÜLLER R, SHINN C, WALDVOGEL AM, OEHLMANN J, RIBEIRO R \& MOREIRA-SANTOS M. 2019. Long-term effects of the fungicide pyrimethanil on aquatic primary producers in macrophyte-dominated outdoor mesocosms in two European ecoregions. Sci Total Environ 665: 982-994.

NICACIO G \& JUEN L. 2015. Chironomids as indicators in freshwater ecosystems: an assessment of the literature. Insect Conserv Divers 8: 393-403.

OKANO J, SHIBATA J, SAKAI Y, YAMAGUCHI M, OHISHI M, GODA Y, NAKANO S \& OKUDA N. 2017. The effect of human activities on benthic macroinvertebrate diversity in tributary lagoons surrounding Lake Biwa. Limnology 19: 199-207.

PINDER L. 1986. Biology of freshwater Chironomidae. Annu Rev Entomol 31: 1-23.

R CORE TEAM. 2016. R: A language and environment for statistical computing. R Foundation for Statistical Computing, Vienna, Austria.

ROQUE FO, CORBI JJ \& TRIVINHO-STRIXINO S. 2000. Considerações sobre a utilização de larvas de Chironomidae (Diptera) na avaliação da qualidade da água de Córregos do Estado de São Paulo. In: Espíndola ELG, Paschoal CMRB, Rocha O, Bohrer MBC \& Neto ALO (Eds), Ecotoxicologia perspectivas para o século XXI, São Carlos: Rima Editora, Brazil, p. 115-126.

ROQUE FO, SIQUEIRA T, BINI LM, RIBEIRO MC, TAMBOSI LR, CIOCHETI G \& TRIVINHO-STRIXINO S. 2010. Untangling associations between chironomid taxa in Neotropical streams using local and landscape filters. Fresh Biol 55: 847-865.

ROSENBERG DM. 1992. Freshwater biomonitoring and Chironomidae. Neth J Aquat Ecol 26: 101-122. 
ROY AH, ROSEMOND AD, LEIGH DS, PAUL MJ \& WALLACE JB. 2003. Habitat-specific responses of stream insects to land disturbances: Biological consequences and monitoring implications. J Amer Benthol Soc 22: 292-307.

SEELAND A, ALBRAND J, OEHLMANN J \& MÜLLER R. 2013. Life stage-specific effects of the fungicide Pyrimethanil and temperature on the snail Physella acuta (Draparnaud, 1805) disclose the pitfalls for the aquatic risk assessment under global climate change. Environ Pollut 174: 1-9.

SEELAND A, OEHLMANN J \& MÜLLER R. 2012. Aquatic ecotoxicity of the fungicide Pyrimethanil: Effect profile under optimal and thermal stress conditions. Environ Pollut 168: 61-169.

SHINN C, DELELLO-SCHNEIDER D, MENDES LB, SANCHEZ AL, MÜLLER R, ESPÍNDOLA EL \& ARAÚJO CV. 2015. Immediate and mid-term effects of Pyrimethanil toxicity on microalgae by simulating an episodic contamination. Chemosphere 120: 407-413.

TANG H, SONG MY, CHO WS, PARK YS \& CHON TS. 2009. Species abundance distribution of benthic chironomids and other macroinvertebrates across different levels of pollution in streams Ann Limnol-Int J Lim 46: 53-66.

TRIVINHO-STRIXINO S. 2011. Larvas de Chironomidae: guia de identificação. São Carlos, Brazil.

TRIVINHO-STRIXINO S \& STRIXINO G. 1995. Larvas de Chironomidae (Diptera) do Estado de São Paulo: Guia de identificação e diagnose de gêneros. São Carlos, Brazil.

VANACKER M, WEZEL A, OERTLI B \& ROBIN J. 2018. Water quality parameters and tipping points of dragonfly diversity and abundance in fishponds. Limnology 19: 321-333.

VERDISSON S, COUDERCHET M \& VERNET G. 2001. Effects of Procymidone, Fluxioxonil and Pyrimethanil on two nontarget aquatic plants. Chemosphere 44: 467-474.

\section{How to cite}

MELLO JL, COLOMBO S, GORNI V \& CORBI GR. 2021. Effects of pyrimethanil fungicide on Chironomidae community structure. An Acad Bras Cienc 93: e20200860. DOI 10.1590/0001-3765202120200860.

\section{JOSÉ LEONARDO DA SILVA MELLO'}

https://orcid.org/0000-0002-9879-8967

\section{VANESSA COLOMBO $0^{1,2}$}

https://orcid.org/0000-0003-3388-7990

\section{GUILHERME ROSSI GORNI,2}

https://orcid.org/0000-0002-9156-6864

\section{JULIANO J. CORBI}

https://orcid.org/0000-0003-0249-9370

${ }^{1}$ Universidade de São Paulo, Departamento de Hidráulica e Saneamento, Escola de Engenharia de São Carlos (EESC), Av. Trabalhador Sãocarlense, 400, 13566-590 São Carlos, SP, Brazil

${ }^{2}$ Universidade de Araraquara, Programa de Pós-Graduação em Desenvolvimento Territorial e Meio Ambiente, Rua Carlos Gomes, 1338, Centro, 14801-340 Araraquara, SP, Brazil

\section{Correspondence to: Juliano José Corbi \\ E-mail: julianocorbi@usp.br}

\section{Author Contributions}

Substantial contribution in the concept and design of the study: Juliano José Corbi. Contribution to data collection: José Leonardo da Silva Mello. Contribution to data analysis and interpretation: José Leonardo da Silva Mello, Guilherme Rossi Gorni and Juliano José Corbi. Contribution to manuscript preparation: José Leonardo da Silva Mello, Guilherme Rossi Gorni, Juliano José Corbi, and Vanessa Colombo. Contribution to critical revision, adding intellectual content: Guilherme Rossi Gorni, Juliano José Corbi, and Vanessa Colombo.

Manuscript received on June 3, 2020;

accepted for publication on February 16, 2021 